\title{
The role of nurses in the integration of care for people with chronic noncommunicable diseases*
}

\author{
Atuação do enfermeiro na integração dos cuidados às pessoas \\ com Doenças Crônicas não Transmissíveis \\ Actuación del enfermero en la integración de cuidados a personas \\ con Enfermedades Crónicas No Transmisibles
}

How to cite this article:

Sousa SM, Bernardino E, Peres AM, Martins MM, Goncalves LS, Lacerda MR. The role of nurses in the integration of care for people with chronic noncommunicable diseases. Rev Esc Enferm USP. 2021;55:e20200131. DOI: https://doi.org/10.1590/1980-220X-REEUSP-2020-0131

\section{Solange Meira de Sousa ${ }^{1}$ \\ Elizabeth Bernardino ${ }^{1}$ \\ Aida Maris Peres ${ }^{1}$ \\ D Maria Manuela Martins ${ }^{1}$ \\ D Luciana Schleder Gonçalves ${ }^{2}$ \\ D Maria Ribeiro Lacerda ${ }^{1}$}

* Extracted from the thesis: "Contribuições do enfermeiro na integração dos cuidados no contexto das Doenças Crônicas não Transmissíveis", Universidade Federal do Paraná, Programa de Pós-Graduação em Enfermagem, 2019.

${ }^{1}$ Universidade Federal do Paraná, Programa de PósGraduação em Enfermagem, Curitiba, PR, Brazil.

${ }^{2}$ Instituto de Ciências Biomédicas Abel Salazar, Escola Superior de Enfermagem do Porto, Porto, Portugal.

\begin{abstract}
Objective: To describe the role of nurses in the integration of care for people with chronic noncommunicable diseases. Method: This was an integrated single-case study conducted with care coordinators and nurses, purposefully selected, with interviews, documentary analysis and computerized files as sources of evidence. Categorical analysis was used based on data organization using MAXQDA ${ }^{\circledR}$ software, version 2018. Results: Thirty-four professionals participated. Most of the professionals who held coordination positions were nurses. The categories clinical team integration and care integration and their subcategories increased understanding of the roles of nurses. Conclusion: The role of nurses in integrating care for people with chronic noncommunicable diseases was mainly focused on coordination of care, which occurred because of the different roles that they play and that give them autonomy to make decisions and place them in the front line to contribute to situations that required assertive attitudes, such as directing users within the care network.
\end{abstract}

\section{DESCRIPTORS}

Comprehensive Health Care; Noncommunicable Diseases; Health Services Administration; Case Reports; Nursing Care; Nurses. 


\section{INTRODUCTION}

Integration consists of a coherent set of methods and models of funding, administration, organization, service delivery, and clinical levels, designed to create connectivity, alignment, and collaboration ${ }^{(1)}$. For clarification purposes, integration is addressed in numerous studies with a focus on health and with different approaches ${ }^{(2-5)}$. In the present study, it is defined as a process that involves creation and maintenance of a common structure between independent parties - individuals or organizations - with the purpose of coordinating their interdependence so as to allow a collective project $^{(4)}$.

Integration is a topic of interest on the agenda of many countries and the World Health Organization (WHO), as it is a necessary resource to face challenges around the world, such as those related to the management of chronic noncommunicable diseases (CNCDs), which require multiple interventions and approaches. In this context, coordination of care, at all levels, represents one of the strategies for integration and is one of the global priorities for redirecting health services to serve the needs of people ${ }^{(6)}$.

Among the agendas discussed that require resolution by the health sector, CNCDs are one of the most relevant problems. In 2016, an estimated 41 million deaths occurred as a consequence of CNCDs, accounting for $71 \%$ of deaths worldwide $^{(7)}$. In Brazil, from 1990 to 2015, CNCDs were the main cause of death among individuals aged 30 to 69 years old $^{(8)}$. However, between 2006 and 2014, early mortality caused by the main four CNCDs (circulatory system diseases, cancer, diabetes mellitus, and chronic respiratory diseases) decreased in the federative units of Brazil and the Federal District ${ }^{(9)}$.

This is a scenario of high mortality rates with a downward trend. Nonetheless, occurrence of CNCDs implies reorganization in the health system and imposes to the State the need to find ways to balance its budget to increase the efficiency of existing resources. Consequently, care integration is a feasible alternative for restructuring this context ${ }^{(4)}$, since there is a long path to be taken to meet the global target defined by the World Health Organization oriented toward reducing mortality by one-third until $2030^{(7)}$.

Despite the progress achieved by the Brazilian Unified Health System (SUS, as per its acronym in Portuguese), among which establishing primary health care as the route of entry into the system stands out, the difficulty of overcoming care fragmentation and qualifying care management remains evident. To sort out these problems, reorganizing the system in healthcare networks, which encompasses coordinated health actions and services aiming to guarantee comprehensive care, is a strategy to restructure the organization, quality, and delivered $\operatorname{care}^{(10)}$. However, these political-organizational changes did not fully solve the problems that prompted these alterations.

To achieve these goals, it is necessary to transform professional and organizational practices, and it becomes indispensable that the insertion of nurses, the development of new functions and roles performed by them, the acquisition of new competences, and the establishment of a closer collaboration with other professionals in an integration context ${ }^{(2)}$ result in a practice that prioritizes global demands, especially those consistent with the needs of more comprehensive care that people affected by CNCDs must receive.

Some contexts exemplify the remarks on the practice of nurses mentioned above. In Madrid, improvements in health outcomes of the population relied on strong nursing leadership, with skills to manage complex cases and the ability to implement comprehensive care programs, mainly in situations of high CNCDs prevalence ${ }^{(11)}$. In Quebec, researchers identified strategies that could be used to support the development of a nursing practice aligned with the requirements of care integration, with nurses playing an important role in this process. Among these strategies, implementing organizational and clinical-administrative processes to promote integration stood out ${ }^{(2)}$.

Therefore, nursing care, in all its nuances, translates into one of the elements of local health systems, with relevant consequences in the broader health system ${ }^{(12-13)}$.

Once the objective of showing how professional practices of nurses contribute to integration of care of people with CNCDs was set for the present study, the authors opted for a theoretical framework that considers integration in three contexts - a system of values, an organizational structure, and a clinical system - that, when coordinated with one another, result in an integrated system encompassing five dimensions: care integration, clinical team integration, functional integration, normative integration, and systemic integration. The first four categories are related to the interaction between individuals and organizations in a situation of interdependence, and the last dimension establishes relationships between a local environment and a broader system ${ }^{(4)}$.

In this reality, in which the complexity of several health problems and the lack of case-resolution capacity caused by care fragmentation coexist, each health professional is assigned to the task of delimiting their professional practice more clearly and effectively. Regarding nurses, this practice includes all positions and functions that are given to them and can contribute individually and collectively to integration.

Nurses have expanded their scope of practice and have been increasingly more decisive and proactive regarding identification of care needs, health promotion and protection, and care coordination. In face of all the functions performed by nurses at all assistance levels, this type of professional offers substantial support in this context of transformation in the health area. Therefore, it is understood that their work in integrating care of people with CNCDs is an important discussion and can conveniently contribute to the review of functions, knowledge, skills, and practices according to organizational and care changes, aiming to bring improvements regarding delivery of comprehensive and continuing care that provides solutions to important health issues.

Care coordination is a global priority to reorient health services according to people's needs. Developing practices 
that aim to improve care continuity and coordination can increase the quality of the care experience of people with chronic diseases and improve the health results and the performance of the system as a whole ${ }^{(6)}$.

By taking into account the scenario described above and by considering that integration is essential for keeping services connected and that, in the primary healthcare context, professionals are responsible for offering diverse care that properly meets the needs of people, the authors formulated the following question: How is the role of nurses played in the integration of care for people with CNCDs? To answer it, the present study had the objective of describing the practice of nurses in the integration of care for people with CNCDs.

\section{METHODS}

\section{Study Design}

This was an integrated single-case study, with an analysis subunit, which had interviews, documentary analysis, and computerized files as sources of evidence. The adopted methodological framework ${ }^{(14)}$ involved two sequential and interdependent phases, with the first consisting of interviews and the second of documentary analysis and search in computerized files.

To meet the requirements of the methodological framework ${ }^{(14)}$, the authors selected care integration as the analysis unit (or the case) and the role of nurses in integration as the analysis subunit integrated to the single case. These choices made it possible to meet one of the requirements of a case study, because the phenomenon (analysis unit and subunit) needs in-depth examination so it can be understood in all its context, while it can also be observed and studied.

\section{Study Setting}

The present study was carried out from August 2016 to June 2017 in a sanitary district of a municipality located in the South Region of Brazil that administers 15 health units. The choice was purposeful, since all districts have the same manager composition and the same matrix configuration, that is, they all have the same functioning logic and the responsibility of providing care centered in people's needs.

Districts are administratively autonomous health regions. Each district has the same management configuration: one director, one health management coordinator, one healthcare coordinator, one health surveillance coordinator, and one coordinator in each health unit. These coordination positions can be held by any health professional, according to criteria defined by the Municipal Health Secretariat (MHS).

The MHS established management agreements, which came into force in 2002, between basic units and sanitary districts and between these and the MHS itself. These agreements provided for negotiations of targets to be discussed with health teams, taking into account the installed capacity and the specificities of each territory ${ }^{(15)}$.

\section{Selection Criteria}

The established inclusion criteria were: being a coordinator in the district (considering all academic degrees) and being a nurse: for coordinators, selection encompassed the director, the health management coordinator, the healthcare coordinator, the health surveillance coordinator, and the local coordinators of the 15 health units in the district; and, for nurses, there was the requirement of being available to participate in the study, and one nurse was randomly picked in each unit. The exclusion criteria were: professionals who were on any type of leave during the data collection period. Only two nurses were unavailable on the scheduled days and, in these situations, other nurses were contacted and new dates were scheduled. All professionals initially considered participated in the study.

\section{Sample Definition}

Participant selection was purposeful, as it included key informers with experience in management and nurses responsible for direct care.

\section{Data Collection}

Data collection was carried out in two phases by a researcher who had, as a starting point, scripts addressing aspects related to the dimensions of integration, designed according to the adopted theoretical framework and drawing upon other pertinent studies ${ }^{(5,16)}$. Regarding the dimensions of integration and the characteristics that define them, the previously defined categories and subcategories, respectively, were considered.

The scripts used to collect data covered the same topics. Chart 1 shows the main items addressed in these instruments, which were connected with the objective of the present study.

In the first phase, individual interviews (primary sources) were carried out with the professionals at their workplaces, whereas the second phase focused on analyzing computerized documents and files (secondary sources) which were selected according to the information made available in the interviews, and allowed data to be compared. Documentary analysis consisted of examination of resolutions, decrees, laws, and a field diary whose objective was to allow the register of aspects of the functioning of services and professional interactions. The computerized files were materials on electronic media available online. Chart 2 summarizes the main selected documents and files.

\section{Data Analysis and Treatment}

The researchers sought to take in the aspects mentioned in the scripts in all sources of evidence considering data relevance, which allowed to identify convergence of information $^{(14)}$. The audio of the interviews was recorded, and their maximum and minimum durations were $1 \mathrm{~h} 24$ ' 31 " and 18 '58", respectively. Subsequently, they were transcribed, resulting in a material with 517 pages.

MAXQDA ${ }^{\circledR}$ software version 2018 was used to help organize and categorize the texts by following some 
steps: 1) each text segment was designated according to the dimensions of integration (categories); 2) the segments were reorganized based on the characteristics of each dimension of integration (subcategories); and 3) for each characteristic, the most meaningful excerpts were selected and summarized. Consequently, the software facilitated the disposition of categorical analysis. In each of these steps, analysis matrixes were designed and organized until they became more compact versions, containing a summary of the most relevant aspects.

Computerized documents and files considered pertinent to the study were examined and used as sources of

Chart 1 - Topics addressed in the data collection instruments Curitiba, PR, Brazil, 2017.

\begin{tabular}{|l|}
\hline $\begin{array}{l}\text { Health actions and care oriented toward the needs of users in the } \\
\text { CNCDs* context. }\end{array}$ \\
\hline $\begin{array}{l}\text { Consistency between the interdisciplinary approach and the } \\
\text { population's needs. }\end{array}$ \\
\hline $\begin{array}{l}\text { Functions of the professionals considering the individual needs of } \\
\text { each user. }\end{array}$ \\
\hline Influence of service management on care integration. \\
\hline Organization of health and nursing care in the CNCDs* context. \\
\hline Management carried out by nurses in care integration. \\
\hline Role of nursing teams in the fulfillment of health needs. \\
\hline Engagement of users in self-care. \\
\hline $\begin{array}{l}\text { Coordination of care practices in the SUS }{ }^{+} \text {network in the CNCDs* } \\
\text { context. }\end{array}$ \\
\hline Coordination of nursing care in the district in the CNCDs* context. \\
\hline $\begin{array}{l}\text { Cooperation between professionals of the multiprofessional team for } \\
\text { delivery of care in the CNCDs* context. }\end{array}$ \\
\hline $\begin{array}{l}\text { Partnerships between professionals considering the individual needs } \\
\text { of each user. }\end{array}$ \\
\hline $\begin{array}{l}\text { Decisions of the professionals regarding the fulfillment of health } \\
\text { needs. }\end{array}$ \\
*CNCDs - chronic noncommunicable diseases; ${ }^{*}$ SUS - Brazilian Unified \\
Health System. \\
\hline
\end{tabular}

information related to the characteristics of each dimension of integration.

Data were analyzed from the perspective of the theoretical framework, and the most meaningful previously defined categories and subcategories (dimensions of integration and their characteristics) stood out because of their relevance to the present study.

\section{ETHICAL Aspects}

The participants were identified by a letter followed by a number in ascending order of execution of the interviews. The letter "N" was used for nurses (N1, N2, .., N15), the letter "C" for coordinators of each health unit $(\mathrm{C} 1, \mathrm{C} 2, \ldots$, $\mathrm{C} 15)$, and the letter " $\mathrm{M}$ " for coordinators and the director of the district (M1, M2, M3, and M4). Data related to the interviews and computerized documents and files were identified by the abbreviations "INT", "CD", and "CF", respectively. The proposal was approved in 2014/2015 by the research ethics committee at the participating institution as per report no. 888,681 and Certificate of Presentation for Ethical Evaluation no. 36975914.5.0000.0102 and by the co-participating institution as per report no. 944,669 and Certificate of Presentation for Ethical Evaluation no. 36975914.5.3002.0101. The criteria described in the instrument Consolidated Criteria for Reporting Qualitative Research were adopted ${ }^{(17)}$.

\section{RESULTS}

Thirty-four professionals participated in the study. Most were women $(91.1 \%)$. The prevalence of age groups was: 31 to 40 years: $41.1 \%$; 41 to 50 years: $29.4 \%$; and 51 to 61 years: $29.4 \%$. Length of experience was six months to two years for $38.2 \%$; three to five years for $32.3 \%$; eight to 10 years for $20.5 \%$; and 15 to 19 years for $8.8 \%$. Most professionals had a degree in nursing $(91.1 \%)$, followed by those with a degree in pharmacy $(8.8 \%)$ and in dentistry (2.9\%). $44.1 \%$ held the position of unit coordinator, the same percentage applied for nurses, and $11.7 \%$ were district coordinators, which included the district director.

Chart 2 - Computerized documents and files selected for data analysis - Curitiba, PR, Brazil, 2017.

\begin{tabular}{|l|l|}
\hline \multicolumn{1}{|c|}{ Documents (CD)/Files (CF) } & \multicolumn{1}{|c|}{ Responsible person/institution and year } \\
\hline Field diary (CD): notes to corroborate the information coming from other data sources. & Researchers. 2016/2017. Personal archive. \\
\hline $\begin{array}{l}\text { Annual operating plan (CD): management tool that favors operationalization of the } \\
\text { targets. }\end{array}$ & Sanitary district. 2015. Made available by the district. \\
\hline $\begin{array}{l}\text { Standard operating procedures (CD): documents that provide resources to the activities } \\
\text { of health professionals. }\end{array}$ & Primary Care Department. MHS. 2017. \\
\hline Wound treatment protocol (CD): document that favors systematization of offered care. & Primary Care Department. MHS. 2015. \\
\hline $\begin{array}{l}\text { Municipal plan (CF): document that guides the implementation of the municipality } \\
\text { health policy. }\end{array}$ & MHS. Municipal government. 2016. \\
\hline $\begin{array}{l}\text { Advanced access booklet (CF): material that provides information on and discusses new } \\
\text { possibilities to organize access. }\end{array}$ & $\begin{array}{l}\text { Primary Care Department. MHS. Municipal government. } \\
\text { 2014. }\end{array}$ \\
\hline $\begin{array}{l}\text { Guideline of care of people with type 2 diabetes mellitus (CF): document that organizes } \\
\text { care of people with diabetes mellitus and work carried out by teams. }\end{array}$ & MHS. Municipal government. 2010. \\
\hline Hypertensives' manual (CF): material that systematizes care of hypertensive people. & MHS. Municipal government. 2004. \\
\hline
\end{tabular}


The composition of coordinators in the district as a whole was essentially nurses. Regarding training, all participants had a graduate degree, $94.1 \%$ of whom with a specialization and $5.8 \%$ with an academic (master's) degree.

The results were described according to the dimensions of integration and their characteristics related to the study objective, that is, two categories and their subcategories, respectively. Examples derived from the sources of evidence that contributed to the understanding of the role of nurses in the integration of care of people with CNCDs followed.

\section{Category 1: Clinical Team Integration}

Category 1 originated two subcategories. The first, entitled Coordination of care carried out by nurses, showed that when these professionals apply their management abilities they can easily establish contact with other professionals. When this characteristic is used in favor of users, it facilitates integration. The examples provided by the sources of evidence illustrated these statements: (...) nurses have a broader, differentiated view, which makes it easier for them to play their management role (...) this is good for the group (...) (INT-M4). Advanced access booklet (CF): provides information that favors use of a universal language between professionals regarding organization of access to the network in the municipality.

In the second subcategory, Coordination of care carried out by other professionals in the health team, it was also possible to identify the importance of the role of nurses, especially in the interaction with local coordinators who have training in different areas, providing support for care, as shown in the examples: (...) because they know the big picture, they can interact well with doctors, the family health support center (...) nurses pervade the entire health unit (...) (INT-M2). Advanced access booklet (CF): provides information that favors use of a universal language between professionals regarding organization of access to the network in the municipality.

\section{Category 2: Care Integration}

Category 2 had four subcategories. The first, Management of services oriented toward the health needs of users, indicated that local coordinators encourage cohesion in teamwork. They guarantee proper management of work schedules, allowing that services are continuous and that users always get what they need. The following examples reinforced these ideas: (...) I have to secure access to health to the population in the region (...) team and materials to meet the citizens' needs (...) (INT-C14). Advanced access booklet (CF): details the organization of access to primary care, with workflows that must be followed by professionals. Municipal plan (CF): guides the implementation of the municipality health plan, which focuses on users' needs. Annual operating plan (CD): consists of a management tool that favors operationalization of targets. All planning of annual targets to be achieved, including aspects related to services management, is present in this document.
The second subcategory, Nursing management oriented toward the health needs of users, showed that care of people with CNCDs imply the daily contribution of nurses to the local manager, which is confirmed when managers coordinate their nursing teams, offering clinical support for the development of group activities or individual care in the health unit. Some sources that illustrate this statement are: You have to become involved with the person, establish bonds (...) you really know that you have diabetes and your feet are like that (...) there is the issue of special dressing, (...) you will follow up that wound (...) (INT-N15). Wound treatment protocol (CD): establishes nursing care in case of wounds. Standard operating procedure manuals (CD): put together the practical nursing procedures oriented toward meeting people's health needs.

According to the third category, Delivery of nursing care is consistent with individual needs, nurses prioritize clinical care oriented toward CNCDs and give more emphasis to users with hypertension and diabetes. In this context, they can define, with their team, the way care will be delivered. Nurses take on several aspects of care and are very requested by both managers, to provide information, and users, to solve problems. The examples extracted from the sources of evidence confirmed these findings: (...) it is a characteristic of nurses, of nursing professionals, they are very integrated because the care part is implicit in their position, their training (INT-M3). Advanced access booklet (CF): emphasizes the importance of the work of nurses and nursing teams to improve access, especially workflows and responsibilities of each professional. The document stresses that care of people with CNCDs must be consistent with the organization defined by each team. Guideline of care of people with type 2 diabetes mellitus $(\mathrm{CF})$ : describes the organization of care of people with diabetes and the role of the teams. Hypertensives' manual (CF): systematizes care of hypertensive people.

The fourth subcategory, Users are engaged in their care processes and have shared responsibility, showed that nurses are characterized as the professional who is on the frontlines of care of patients with CNCDs. Therefore, they are more demanded regarding responsibility and commitment in prevention and follow-up, at the expense of advocated self-care. The examples found in the accounts grounded the synthesis of this subcategory: nurses are very responsible when it comes to guiding on self-care, (...) but the basis of it all is user engagement (INT-C1). (...) they do not take responsibility. They think that everything has to be done by the unit (...) they really want to hold the health unit accountable (...) (INT-C9). Advanced access booklet (CF): emphasizes the importance of the work of nurses to improve access and services offered to users.

\section{DISCUSSION}

The contributions of nurses were greater from the perspective of two dimensions of integration: clinical team integration and care integration, which suggested a role more aligned with practical and care aspects. The results pointed to integrated and individual-centered care and coordination 
as an important attribute of nurses, in addition to the fact that it is a function taken on by most of these professionals.

The coordinators who participated in the present study had degrees in different areas, with nursing standing out as the prevailing one ${ }^{(18)}$. Nurses occupying coordination positions showed a marked aptitude to deal with the population and, from the perspective of network work, they proved professionals with a remarkable capacity ${ }^{(19)}$ to coordinate with the district managers and did their job efficiently.

Care integration must be addressed from a perspective that considers it as a continuous and dynamic process. Therefore, constant efforts are necessary to align professional, organizational, and institutional aspects by means of which professionals, managers, and policy makers structure their work $^{(20)}$. Coordinators have attributes that allow them to carry out integration, especially because of the dynamics of power found in the services in which they develop their activities. Additionally, in a situation of interdependence, coordinators desire constant cooperation so teamwork can occur, recognizing the role played by each member and formulating strategies that contribute to the achievement of common goals ${ }^{(21)}$.

A study that sought to examine barriers to and facilitators of change in the workforce in integrated care of people with CNCDs pointed to cooperation as a facilitator. It also found that the active participation of nurses favors collaboration of professionals ${ }^{(19)}$. Nevertheless, cooperation between professionals consulted in the present study was made easier by the work of coordinators, which allows care to be more user-centered and offered in a more coordinated way ${ }^{(22)}$.

In a study with English health professionals, some accounts showed that integration was complex and challenging, regarding organizational and professional aspects, as well as those related to services. The challenges to achieving integration involved, above all, human work ${ }^{(3)}$. Work organization, full-time availability, and knowledge of the dynamics of the units in which local coordinators develop their activities are aspects related to their professional practice that make them effective in integrating clinical teams.

Nurses are members of health teams who have information and important characteristics, such as ability to coordination, initiative, and diplomacy to deal with certain situations, that allow them to coordinate health services. These, among other attributes, suggest that coordination is inherent in nursing and that professionals in this area not only occupy coordination positions but bring it along because it is part of their training.

Nurses' work is recognized and adapts as CNCDs become more prevalent. As a consequence, they are allocated to new tasks, given the high care demand and the ability to solve problems shown by these professionals. Inserting nurses into this context of fighting CNCDs can be favorable considering that care integration skills, inherent in nurses' work process $^{(11)}$, can be a strategy to achieve comprehensive care and have the potential to minimize barriers between care levels.

Nurses, together with their nursing teams, contribute substantially to integration of care of users with CNCDs by carrying out interventions aiming to change patients' lifestyle, such as health education, individual care, group meetings, and home visits ${ }^{(23)}$. Nurses play a leading role in this context since they define, with the support of all the team of professionals, the organization of care to be delivered and establish the conducts that must be applied, always backed by the district.

In this scenario, self-care is indispensable to users with CNCDs such as diabetes ${ }^{(24)}$, since the level of commitment of these patients is directly proportional to the success of delivered care. This goes against the attitude some users have of assigning the main responsibility for their health to a professional.

This aspect of self-care raises many reflections. One of them is the fact that the training received by nurses must provide them with the ability of working in teams so they can be a safe link between individuals and other professionals in a situation that favors care in all its interfaces. Additionally, the received training must allow nurses to understand that, although self-care demands great effort by users to be applied, finding strategies that help them when this commitment does not exist is a responsibility to be assumed by these professionals.

People affected by CNCDs require increasingly better care, which poses many challenges. Coordinators are faced with the need for increasingly integrated and comprehensive care coordination, involving all professionals, whereas nurses and other professionals in the team have to show commitment with delivered care that can go beyond their comfort zone and allow them to show their potentialities, recognizing each type of attribution.

Coordination, cited as one of the strategies to achieve integration, can be favored by the availability of services in a network, designing them to be user-centered, and making them be easily accessed by means of the establishment of an entry point into the system so there is support to people's needs. This configuration allows that each professional provides the same individual with more accessible, coordinated, and comprehensive care over time ${ }^{(6)}$ and facilitates adoption of measures oriented toward increasing users' adherence and commitment to attitudes that will benefit their health.

A widened view of the population's health problems is necessary. For nurses, this broadened picture is imperative for their actions to be oriented toward delivering continuous and comprehensive care, encompassing political and organizational aspects. In addition, nurses' professional practice includes different possibilities that must be considered to expand their insertion into this context, because their care, administrative, and educational functions give them a distinguished position in the team of professionals and equip them with resources to deliver better care to users.

Some limitations of the present study must be emphasized. Three dimensions of integration were not described because they did not cover all the perspectives that would make their analysis more detailed considering the study objective. This showed that the dimensions that were not addressed in the study, more related to normative and functional aspects of the district and the health system 
as a whole, need to be analyzed by professionals from a more comprehensive perspective.

All the dimensions of integration must be aimed for in a system to promote delivery of continuous and high-quality care. The dimensions clinical team integration and care integration are essential components to achieve integration and are put into practice in the daily contact between professionals and the relationships established between them. In these relationships, nurses are an important link in the team chain, guaranteeing that offered care has quality, either by carrying out direct care or coordinating a service.

In terms of advances in the scientific field, the authors highlight the description of several attributes of nurses, including problem-solving ability, protagonism and autonomy to organize care, and ability to interact with other professionals. The description of aspects of integration little addressed in the literature, which can contribute to the dissemination of consistent, individual-centered practices, also stood out. Regarding especially primary health care, delivering high professional performance to meet increasingly complex health needs is fundamental. Therefore, as far as nursing goes, coordination is a strong characteristic, and nurses can put it into practice by means of a formal position or not, contributing to integration of care of people with CNCDs.

The authors suggest that future studies examine the experiences of people who received care from the perspective of each dimension of integration.

\section{CONCLUSION}

The impact of CNCDs, that is, the morbimortality and the costs in health systems associated with this group of diseases, calls for the need to reorganize health systems to promote care integration, which must be emphasized to strengthen SUS in the production of care of people with CNCDs. In this scenario, the importance of the role played by nursing must be marked out.

The attributes linked with nurses in the present study (ability to solve problems, protagonism and autonomy to organize care, ability to interact with other professionals, and, notably, coordination) enable them for more assertive referrals through the network and contribute to the role they play with patients with chronic diseases, impacting integration.

Although nurses are not the only professionals who can manage a unit or a district, considering the higher number of coordinators with a nursing degree and the aspects brought up by the present study, it is possible to infer that nurses show remarkable management skills and stand out in coordination of services and districts, that is, different positions and functions that not necessarily involve direct care but that undoubtedly impact it. Consequently, coordination translates as an attribute and an assignment for nurses, given that, once these professionals take a position involving this feature, they stand out for their performance.

In conclusion, the role of nurses in the integration of care of people with CNCDs is focused mainly on care coordination, made possible by means of the different positions taken in the district and in each service, which provide nurses with autonomy to make decisions related to care and the possibility of being frontline professionals regarding contributing to situations that require assertive positions, such as directing users in the care network.

\section{RESUMO}

Objetivo: Descrever a atuação do enfermeiro na integração dos cuidados às pessoas com Doenças Crônicas não Transmissíveis. Método: Estudo de caso único integrado realizado com coordenadores e enfermeiros assistenciais, selecionados intencionalmente, tendo como fontes de evidências entrevistas, análise documental e arquivos computadorizados. Utilizou-se análise categorial a partir da organização dos dados com o software MAXQDA ${ }^{\circledR}$, versão 2018. Resultados: Participaram 34 profissionais. A composição dos profissionais que exercem a coordenação é essencialmente de enfermeiros. As categorias Integração da Equipe Clínica e Integração dos Cuidados e suas respectivas subcategorias favoreceram o entendimento acerca da atuação do enfermeiro. Conclusão: A atuação do enfermeiro na integração dos cuidados às pessoas com Doenças Crônicas não Transmissíveis se concentra principalmente na coordenação do cuidado, possibilitada por meio de diferentes cargos assumidos que lhe conferem autonomia para tomada de decisão, além de ele estar na linha de frente para contribuir com situações que exigem posicionamentos assertivos, como o direcionamento dos usuários na rede de cuidados.

\section{DESCRITORES}

Assistência Integral à Saúde; Doenças não Transmissíveis; Administração de Serviços de Saúde; Relatos de Casos; Cuidados de Enfermagem; Enfermeiras e Enfermeiros.

\section{RESUMEN}

Objetivo: Describir la actuación del enfermero en la integración de cuidados a personas con Enfermedades Crónicas No Transmisibles. Método: Estudio de caso único integrado realizado con coordinadores y enfermeros asistenciales elegidos intencionalmente, con fuentes de evidencias en entrevistas, análisis documental y archivos informáticos. Aplicado análisis categorial sobre datos organizados con software MAXQDA ${ }^{\circledR}$ versión 2018. Resultados: Participaron 34 profesionales. La composición de profesionales con rol de coordinación es esencialmente de enfermeros. Las categorías Integración del equipo clínico e Integración de cuidados, y sus respectivas subcategorías, favorecen entender la actuación del enfermero. Conclusión: La actuación del enfermero en la integración de cuidados a personas con Enfermedades Crónicas No Transmisibles se concentra en coordinar el cuidado, con respaldo en los cargos asumidos que confieren autonomía para toma de decisiones, además de estar en primera línea para contribuir en situaciones que exigen posturas asertivas, como la derivación de pacientes.

\section{DESCRIPTORES}

Atención Integral de Salud; Enfermedades no Transmisibles; Administración de los Servicios de Salud; Informes de Casos; Atención de Enfermería; Enfermeras y Enfermeros. 


\section{REFERENCES}

1. Suter E, Oelke N, Silva Lima MAD, Stiphout M, Janke R, Witt RR, et al. Indicators and Measurement Tools for Health Systems Integration: A Knowledge Synthesis. Int J Integr Care. 2017;17(6):4. DOI: https://doi.org/10.5334/ijic.3931.

2. Longpré $\mathrm{C}$, Dubois CA. Fostering development of nursing practices to support integrated care when implementing integrated care pathways: what levers to use? BMC Health Serv Res. 2017;17:790. https://doi.org/10.1186/s12913-017-2687-0.

3. Mitchell C, Tazzyman A, Howard SJ, Hodgson D. More that unites us than divides us? A qualitative study of integration of community health and social care services. BMC Fam Pract. 2020;21(1):96. DOI: https://doi.org/10.1186/s12875-020-01168-z.

4. Contandriopoulos AP, Denis JL, Touati N, Rodriguez C. The integration of health care: dimensions and implementation. Montréal: Université de Montréal; 2003.

5. Valentijn PP, Boesveld IC, Klauw DM, Ruwaard D, Struijs JN, Molema JJW, et al. Towards a taxonomy for integrated care: a mixed-methods Study. Int J Integr Care. 2015;15:e003. DOI: https://doi.org/10.5334/ijic.1513.

6. World Healt Organization. Continuity and coordination of care: A practice brief to support implementation of the WHO Framework on integrated people-centred health services. Geneva: WHO; 2018.

7. World Healt Organization. Monitoring health for the sustainable development goals. Geneva: WHO; 2018.

8. Malta DC, França E, Abreu DMX, Perillo RD, Salmen MC, Teixeira RA, et al. Mortality due to noncommunicable diseases in Brazil, 1990 to 2015, according to estimates from the Global Burden of Disease study. Sao Paulo Med J. 2017;135(3):213-21. DOI: https://doi. org/10.1590/1516-3180.2016.0330050117.

9. Confortin SC, Andrade SR, Draeger VM, Meneghini V, Schneider IJC, Barbosa AR. Premature mortality caused by the main chronic noncommunicable diseases in the Brazilian states. Revista Brasileira de Enfermagem. 2019;72(6):1588-94. DOI: https://doi. org/10.1590/0034-7167-2018-0701.

10. Brasil. Ministério da Saúde. Portaria n. 4.279, de 30 de dezembro de 2010. Estabelece diretrizes para a organização da Rede de Atenção à Saúde no âmbito do Sistema Único de Saúde (SUS) [Internet]. Brasília; 2010 [cited 2019 Mar 03]. Available from: http://conselho.saude. gov.br/ultimas_noticias/2011/img/07_jan_portaria4279_301210.pdf.

11. Lapeña-Moñux YR, Palmar Santos AM, Martínez González O, Maciá Soler ML, Orts Cortes MI, Pedraz Marcos A. La enfermera ante el reto de la gestión del paciente crónico complejo. Revista ROL de enfermería [Internet] 2017 [cited 2020 Feb 02];40(2):130-6. Available from: https://dialnet.unirioja.es/servlet/articulo?codigo=5837081.

12. Maffissoni AL, Vendruscolo C, Trindade LL, Zocche D. Health care networks in nursing training: interpretations based on primary health care. Revista Cuidarte. 2018;9(3):2309-21. DOI: https://doi.org/10.15649/cuidarte.v9i3.549.

13. Thumé E, Fehn AC, Acioli S, Fassa MEG. Training and practice of nurses for Primary Health Care - advances, challenges, and strategies to strengthen the Unified Health System. Saúde Debate [Internet]. 2018 [cited 2019 Apr 23];42(1 Suppl):275-88. Available from: http:// www.scielo.br/pdf/sdeb/v42nspe1/0103-1104-sdeb-42-spe01-0275.pdf.

14. Yin RK. Estudo de caso: planejamento e métodos. 5ª ed. Porto Alegre: Bookman; 2015.

15. Ditterich RG, Zermiani TC, Moysés ST, Moysés SJ. A contratualização como ferramenta da gestão na Atenção Primária à Saúde na percepção dos profissionais da Secretaria Municipal de Saúde de Curitiba, Brasil. Saúde Debate. 2015;39(spe):207-20. DOI: https://doi. org/10.5935/0103-1104.2015S005323.

16. Hartz ZMA, Contandriopoulos AP. Comprehensive health care and integrated health services: challenges for evaluating the implementation of a "system without walls". Cad Saúde Pública [Internet]. 2004 [cited 2019 Apr 18];20(Supl 2):S331-S336. Available from: http://www. scielo.br/pdf/csp/v20s2/26.pdf.

17. Tong A, Sainsbury P, Craig J. Consolidated criteria for reporting qualitative research (COREQ): a 32 -item checklist for interviews and focus groups. International Journal for Quality in Health Care. 2007;19(6):349-57. DOI: https://doi.org/10.1093/intqhc/mzm042.

18. Nunes LO, Castanheira ELR, Dias A, Zarili TFT, Sanine PR, et al. Importance of local management for delivery of primary health care according to Alma-Ata principles. Rev Panam Salud Publica. 2018;42:e175. DOI: https://doi.org/10.26633/RPSP.2018.175.

19. Busetto L, Luijkx K, Calciolari S, Ortiz LGG, Vrijhoef HJM. Barriers and Facilitators to Workforce Changes in Integrated Care. Int J Integr Care. 2018;18(2):17. DOI: https://doi.org/10.5334/ijic.3587.

20. Glimmerveen L, Nies H, Ybema S. Citizens as Active Participants in Integrated Care: Challenging the Field's Dominant Paradigms. Int J Integr Care. 2019;19(1):6. DOI: https://doi.org/10.5334/ijic.4202.

21. Sousa SM, Bernardino E, Crozeta K, Peres AM, Lacerda MR. Integrality of care: challenges for the nurse practice. Rev Bras Enferm. 2017;70(3):504-10. DOI: https://doi.org/10.1590/0034-7167-2016-0380.

22. Lemetti T, Voutilainen P, Stolt M, Eloranta S, Suhonen R. An Enquiry into Nurse-to-Nurse Collaboration Within the Older People Care Chain as Part of the Integrated Care: A Qualitative Study. Int J Integr Care. 2017;17(1):5. DOI: https://doi.org/10.5334/ijic.2418.

23. Teston EF, Spigolon DN, Maran E, Santos AL, Matsuda LM, Marcon SS. Nurses' perspective on health education in Diabetes Mellitus Care. Rev Bras Enferm. 2018;71(6 Supl):2735-42. DOI: https://doi.org/10.1590/0034-7167-2018-0396.

24. Amaral RT, Barbosa AM, Teixeira CC, Brandão LGVA, Afonso TC, Bezerra ALQ, et al. Knowledge of diabetics about disease and selfcare. Rev enferm UFPE on line [Internet]. 2019 [cited 2020 Mar 13]; 13(1):346-52. Available from: https://periodicos.ufpe.br/revistas/ revistaenfermagem/article/view/239077/31283. 


\section{ACKNOWLEDGEMENTS}

The present study is part of the multicenter project coordinated by professor Elizabeth Bernardino and entitled Estratégias de Integração em Rede: Contribuiçôes do Enfermeiro, presented to the graduate program in nursing at the Federal University of Paraná.

Financial support

Funded by a public notice of the Brazilian National Council for Scientific and Technological Development. It also had the support of the Coordination for the Improvement of Higher Education Personnel as per Funding Code 001.

(cc) BY This is an open-access article distributed under the terms of the Creative Commons Attribution License. 